\title{
EMPLOYING GIS TECHNIQUES AND UNSUPERVISED LEARNING TO DELINEATE GROUNDWATER RECHARGE POTENTIAL: A CASE STUDY IN THE KARST REGION OF NORTHERN PUERTO RICO
}

\author{
Luisa I. Feliciano-Cruz \\ University of Puerto Rico, Mayagüez, Puerto Rico, 00681, luisa.feliciano@upr.edu \\ Ingrid Y. Padilla \\ University of Puerto Rico, Mayagüez, Puerto Rico, 00681, ingrid.padilla@upr.edu \\ Jonathan Muñoz-Barreto \\ University of Puerto Rico, Mayagüez,Puerto Rico,00681, jonathan.munoz@upr.edu
}

\section{Sarah J. Becker}

US Army Corps of Engineers Engineer Research \& Development Center, Geospatial Research Laboratory, Alexandria,VA22315-3864,sarah.j.becker@erdc.dren.mil

\begin{abstract}
Severe drought conditions, along with excessive water extraction, has imposed huge stress on groundwater resources in many regions across the world. Knowledge of potential recharge zones can provide authorities valuable data regarding groundwater resource management, land development, or environmental protection. This study evaluates the feasibility of using geographical information system (GIS) data and unsupervised learning, along with high-resolution World-View satellite imagery to determine potential recharge areas in the karst region of northern Puerto Rico. Groundwater recharge parameters, such as geology, precipitation, lineament density, drainage density, topographic wetness index, slope, land use/cover and sinkhole density were generated as GIS layers and analyzed for groundwater recharge potential, employing principal component analysis in ArcGIS Pro and Environment for Visualizing Images (ENVI). The map generated categorizes groundwater potential zones into four categories: high, moderate, low, and very low. Results revealed that the study area shows a $76 \%$ moderate-to-high groundwater recharge capability in the study area. Even though this methodology was implemented as a case study, it can certainly be extrapolated to other regions and can provide critical information regarding sustainable groundwater resource management.
\end{abstract}

\section{Introduction}

Karst topography, consisting primarily of soluble rocks such as limestone and dolomite, experiences considerable dissolution that creates joints, fractures, and other conduits through which groundwater can flow (Steele-
Valentín and Padilla, 2009). The distinctive features in karst terrains include surface and subsurface features associated with sinkholes, springs, and caves, as well as sinking, losing, and gaining streams (Ford and Williams, 2013). Sinkholes, sinking streams and other surface features provide for direct recharge into karst aquifers, which are characterized by well-developed conduit porosity and highly transmissive zones. Karst systems naturally develop flow routes originating in surface recharge zones that later transmit water to the phreatic zone, and from the phreatic zone, groundwater travels horizontally to discharge points, including emerging in hydraulically connected springs, lakes, rivers and wells (Todd, 2009).

Underlying about $20 \%$ of the planet's ice-free continental area, karst areas provide roughly $20-25 \%$ of the global population's water needs (Ford and Williams, 2013). In the USA, karst systems underlay about $18 \%$ of the continent (Weary and Doctor, 2014) and provide over $40 \%$ of the groundwater used for drinking purposes (Veni et al., 2001). In Puerto Rico, karst areas cover over 17\% of the island (Veve and Taggart, 1996) and produce significant amounts of water for municipal, industrial, agricultural, and ecological integrity. The karst aquifer system of northern Puerto Rico is the most productive aquifer of the island, serving as a significant source of drinking water and supporting important ecosystems. In 2004 and 2005, groundwater provided over $50 \%$ of the water supply to the region, and over $8 \%$ of the total water production in Puerto Rico (MolinaRivera et al., 2008). 
The occurrence, flow and recharge of groundwater is governed by the interrelationship of factors, such as geology, lineaments, slope, drainage density, and land use/ land cover (Jha et al., 2010; Chowdhury et al., 2010). Advances in remote sensing (RS) technology and software have made it possible for many researchers to employ geographical information systems (GIS) for studying groundwater recharge. Methodologies such as multi-criteria decision analysis (MCDA), analytical hierarchy process (AHP) and groundwater potential index (GWPI) have been used for identifying groundwater recharge zones and for determining the relative weight of thematic layer parameters to categorize an area's recharge potential (Jha et al., 2010; Chandio et al., 2013; Andualem and Demeke, 2019).

The groundwater recharge potential zone has been assessed in many regions. However, it has not yet been assessed in Puerto Rico, particularly in the northern karst region. This investigation aims to: (1) study the weights of different parameters for groundwater recharge potential based on the characteristics of the Arecibo region (2) develop thematic layers for the study site, (3) delineate suitable groundwater potential zones through the integration of these thematic layers, and (4) demonstrate the capabilities of remote sensing, unsupervised learning, and GIS in potential groundwater resource mapping.

\section{Study Site}

The study area encompasses the Tallonal Natural Reserve, near the Tanamá River, a tributary to the Rio Grande de Arecibo in Puerto Rico. This reserve is located in the northern karst region of Puerto Rico, $7 \mathrm{~km}$ to the southwest of Arecibo near $-66.73 \mathrm{~N}$ and $18.405 \mathrm{~W}$ (Figure 1). This region extends $125 \mathrm{~km}$ to the east and west along the north coast from Loíza to Aguada, with a maximum width of $23 \mathrm{~km}$ near Arecibo (Monroe, 1976). According to the Köppen climate classification, the cli-

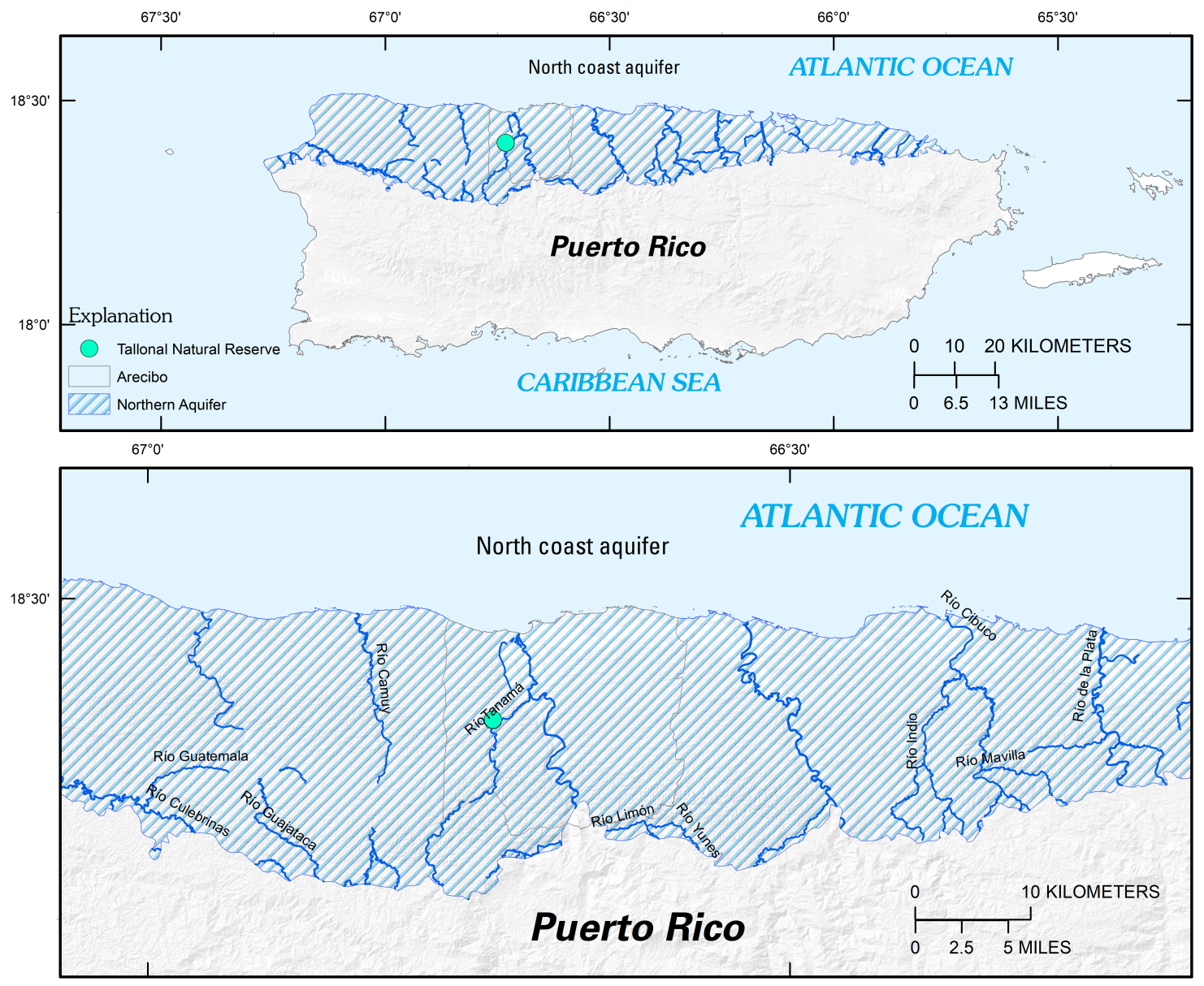

Figure 1. Location of the Tallonal Natural Reserve study site with respect to the north coast aquifer, Puerto Rico. Major rivers near the area include Río Grande de Arecibo and Río Tanamá. 
mate in the region can be classified as tropical humid and is dominated by easterly trade winds. Mean annual rainfall ranges from $1525 \mathrm{~mm}$ along the coast to $1775 \mathrm{~mm}$ near the southern limit of the study area (Torres-Gonzalez et al., 1996). The weather is characterized by warm and rainy summers and dry winters. Temperature averages $85^{\circ} \mathrm{F}$.

\section{Methodology}

The groundwater recharge potential in the study area was generated using GIS through the integration of eight thematic information layers for the area: geology, precipitation, lineament density, drainage density, topographic wetness index, slope, and land use/land cover (LULC), and sinkhole density. The pre-processing analysis of remote sensing data was carried out using student versions of ArcMap 10.7, PCI Geomatica 2018 and ENVI 5.2. WorldView-2 panchromatic imagery of $0.46 \mathrm{~m}$ resolution, and eight-band multispectral imagery with 1.84 m resolution for 20 January 2016 was provided by Dr. Becker (USACE, personal communication) and was used to develop the lineament density thematic layer. The NOAA Office for Coastal Management provided a 3-m digital elevation model (DEM) of the area (Pendleton 2018, personal communication), which was used to develop the drainage density, topographic wetness index, and slope thematic layers. Thematic layers for the geology and land cover/land use were processed from data obtained in the local government GIS internet portal (http://www.gis.pr.gov/). Annual average rainfall data was obtained from a rainfall map produced by the National Weather Service: (https://www.weather.gov/ images/sju/hydrology/2010 ncdc_precip_normals PR USVI.jpg). Sinkhole density data was provided by Torres et al. (2018), redrawn from Giusti (1978).

\section{Multi-Criteria Decision Analysis (MCDA)}

An MCDA was conducted to assign a weight to each parameter within a thematic layer. The values selected were based on similar studies from literature, and through engineering judgment, taking hydrogeological factors and field conditions of the study area into account. The weight indices for each parameter of the different thematic layers (ranging from 0 to 5 ) that contribute to groundwater recharge are provided in Table 1 and will be discussed in further detail.

Following the Groundwater Potential Index (GWPI) method proposed by Malczewski (1999), a groundwa-

\begin{tabular}{|c|c|c|}
\hline \multicolumn{2}{|c|}{ Parameter } & \multirow{2}{*}{$\begin{array}{c}\text { Weight } \\
3\end{array}$} \\
\hline Land Use & Agriculture & \\
\hline & Bare & 2 \\
\hline & Forest & 4 \\
\hline & Urban/Rural & 1 \\
\hline & Water & 5 \\
\hline \multirow[t]{5}{*}{ Geology } & Sand Deposits & 0 \\
\hline & Alluvium & 2 \\
\hline & Swamp Deposits & 0 \\
\hline & Limestone & 5 \\
\hline & Volcanic & 1 \\
\hline Precipitation & $1600-1700$ & 1 \\
\hline \multirow[t]{4}{*}{$(\mathrm{mm})$} & $1700-1800$ & 2 \\
\hline & $1800-1900$ & 3 \\
\hline & $1900-2000$ & 4 \\
\hline & $2000-2100$ & 5 \\
\hline \multirow[t]{5}{*}{ TWI } & $-15--8$ & 1 \\
\hline & $-8-0$ & 2 \\
\hline & $0-8$ & 3 \\
\hline & $8-16$ & 4 \\
\hline & $16-26$ & 5 \\
\hline Drainage & $0-75$ & 1 \\
\hline density & $75-125$ & 2 \\
\hline \multirow[t]{3}{*}{$\left(\mathbf{m} / \mathbf{m}^{2}\right)$} & $125-175$ & 3 \\
\hline & $175-225$ & 4 \\
\hline & $225-275$ & 5 \\
\hline Lineament & $0-125$ & 1 \\
\hline density & $125-250$ & 2 \\
\hline \multirow[t]{3}{*}{$\left(\mathbf{m} / \mathbf{m}^{2}\right)$} & $250-375$ & 3 \\
\hline & $375-500$ & 4 \\
\hline & $500-625$ & 5 \\
\hline Slope & 0 to 1 & 5 \\
\hline \multirow[t]{4}{*}{ (degrees) } & 1 to 5 & 4 \\
\hline & 5 to 20 & 3 \\
\hline & 20 to 45 & 2 \\
\hline & 45 to 90 & 1 \\
\hline Sinkhole density & $0-1$ & 0 \\
\hline \multirow[t]{5}{*}{$(\%)$} & 1 to 10 & 1 \\
\hline & 11 to 20 & 2 \\
\hline & 21 to 40 & 3 \\
\hline & 41 to 60 & 4 \\
\hline & $60+$ & 5 \\
\hline
\end{tabular}

Table 1. Parameters and weights considered for the study. 
ter recharge potential map (GWRPM) of the study area was generated by integrating all the thematic layers that are expected to contribute to groundwater recharge. The weighted overlay tool in ArcGIS was employed for this purpose. The percent of influence for each thematic layer was, as in the case of the parameter weights, based on those found in the literature (Chowdhury, 2010; Da Costa et al., 2019; Andualem and Demeke, 2019) and were modified to consider local hydrogeological factors and field conditions of the study area (Torres-Gonzalez, 1985; Torres et al., 2018; Torres et al., 2019). The percent influence for each thematic layer is provided in Table 2.

\section{Geology}

The geology of the area surrounding the study site is dominated by Tertiary-era limestone outcrops which form three aquifer systems: the north coast limestone aquifer-upper within the Aguada and Ayamón limestone formations; the lower aquifer within the Lares limestone and the Cibao formation; and the alluvial valley aquifer (Yu et al., 2015). The erosion and dissolution of limestone bedrock have resulted in the formation of karstic hills or mogotes (Figure 2) within a flat coastal corridor and alluvial valley, part of the Río Grande de Arecibo floodplain (Monroe, 1976).

Five main geologic units were considered for this layer: sand and swamp deposits, limestone, alluvium, and volcanic rock. Particularly the sand and swamp deposits have developed by dissolution of the limestone surface that surrounds the mogotes. In these sand and swamp deposits along the north coast lies the most important groundwater drainage feature in the study area. Caño Tiburones, a low-lying area parallel to the coast, is approximately $20 \mathrm{~km}$ in length and $2.5 \mathrm{~km}$ in width, between the Río Grande de Arecibo and Río Grande de Manatí (Tor-

\begin{tabular}{lc}
\hline \multicolumn{1}{c}{ Parameter } & \% Influence \\
\hline TWI & 5 \\
Lineament density & 15 \\
Drainage density & 10 \\
Precipitation & 15 \\
Geology & 15 \\
Land use & 10 \\
Slope & 10 \\
Sinkhole density & 20 \\
\hline
\end{tabular}

Table 2. Percent of influence for the different thematic layers.

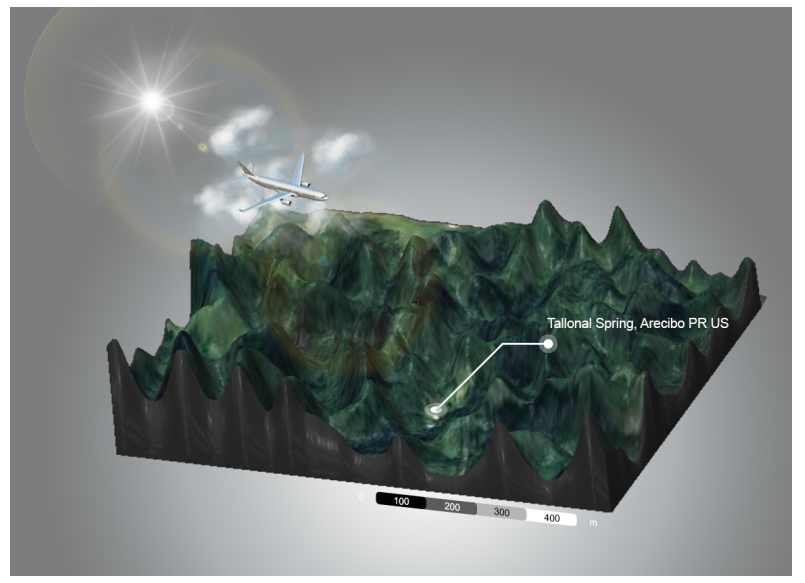

Figure 2. Karstic hills in the study area.

res-Gonzalez et al., 1996). Several canals and low-lift turbine pumps help drain surface runoff and groundwater discharge from Caño Tiburones towards the Atlantic Ocean (Torres-Gonzalez et al., 1996). Since this area is a groundwater discharge zone, it cannot be considered a potential groundwater recharge area. To account for this, a binary thematic layer was created, where the value of zero was assigned to the sand and swamp deposit drainage areas, and a value of one was assigned to represent the study area to the south that can potentially contribute to recharge. Hence, the study area will not contain this region to the north. The resulting geology thematic layer is shown in Figure 3.

\section{Precipitation}

The annual average rainfall in the northern karst region ranges from 1300 to $2500 \mathrm{~mm}$ (Monroe, 1976). The dry season runs between December and April, while the rainy season runs between May and November. Data from the National Weather Service for the entire island between 1981 and 2010 was digitized and interpolated through an inverse distance weighting (IDW) method using GIS (ESRI, 2019) to generate a precipitation raster (Figure 4) for analysis.

\section{Lineament Density}

Lineaments, naturally occurring features on Earth's surface, can reflect underlying geological structures related to faults, linear sink holes or fracture zones (Dasgupta and Mukherjee, 2018). Since lineaments usually serve as conduits for groundwater in the subsurface, they can yield critical information on subsurface features that may control the movement and/or storage of groundwater (Abdullahi et al., 2013). Lineaments may often be apparent in geological or topographic maps or satellite images, since 


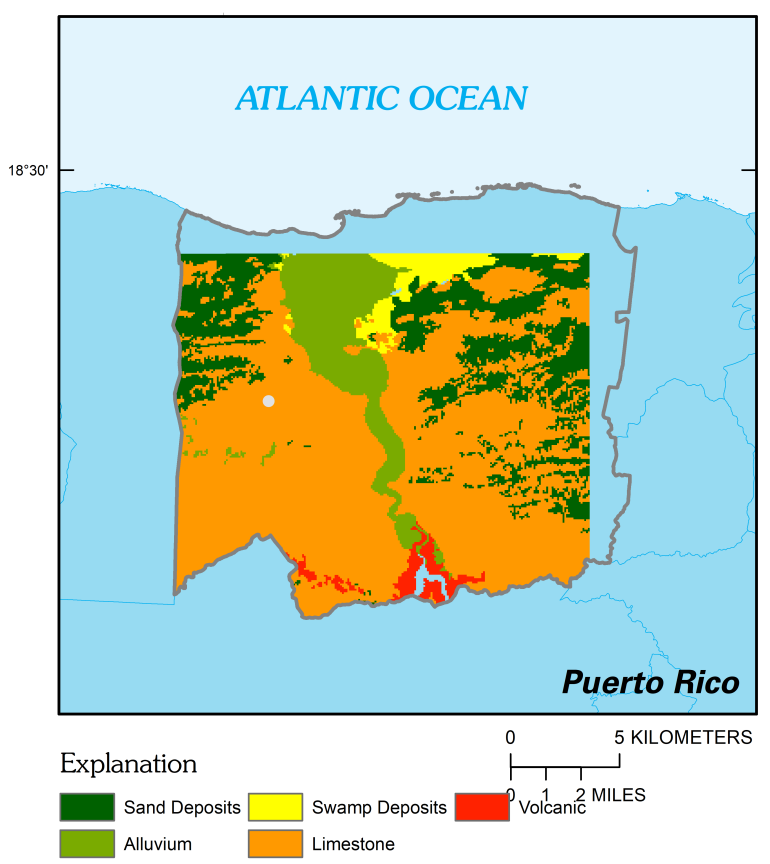

Figure 3. Geology thematic layer for the study area.

they usually appear as lines or linear formations whose pixels differ from the background pixels. Most lineament mapping is done visually using enhanced images. However, visual analysis is time consuming and subjective. As a means to improve objectivity of lineament analysis,

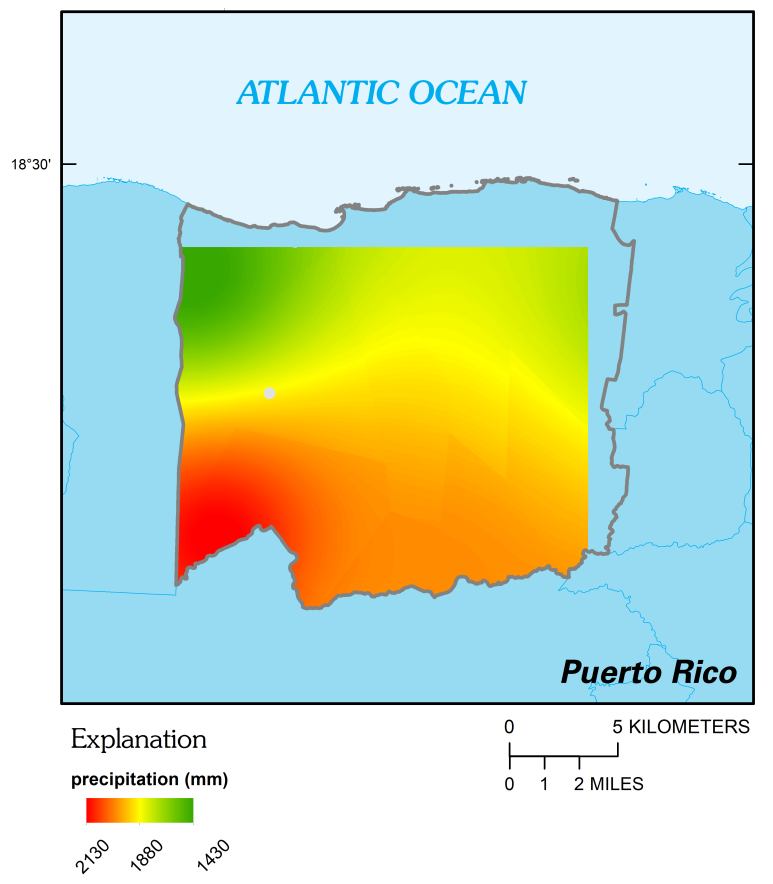

Figure 4. Precipitation thematic layer for the study area. automated lineament detection methods, such as principal component analysis (PCA), can be employed. According to the ENVI 5.2 help documentation, PCA is an unsupervised learning method that employs matrix operations to calculate a projection of the original data into fewer dimensions. In other words, PCA transforms the original satellite imagery, which is usually highly correlated, into a new set of uncorrelated variables called principal components. The benefits of the technique from a geological standpoint are mainly that information not visible in false color composite images can be highlighted in PCA. A lineament density thematic map for the study area (Figure 5) was generated using PCA in ENVI 5.2 and the LINE module in PCI Geomatica 2018.

LINE extracts linear features from an image and records the polylines in a vector layer to extract lineaments. The default parameters were used.

\section{Drainage Density}

The drainage density has been correlated with groundwater recharge (Jha et al., 2010; Chowdhury et al., 2010) and discharge components. The extraction and analysis of the drainage density for the study area (Figure 6) was conducted based on flow direction and flow accumulation computed from the DEM and was obtained through the line density tool in ArcGIS.

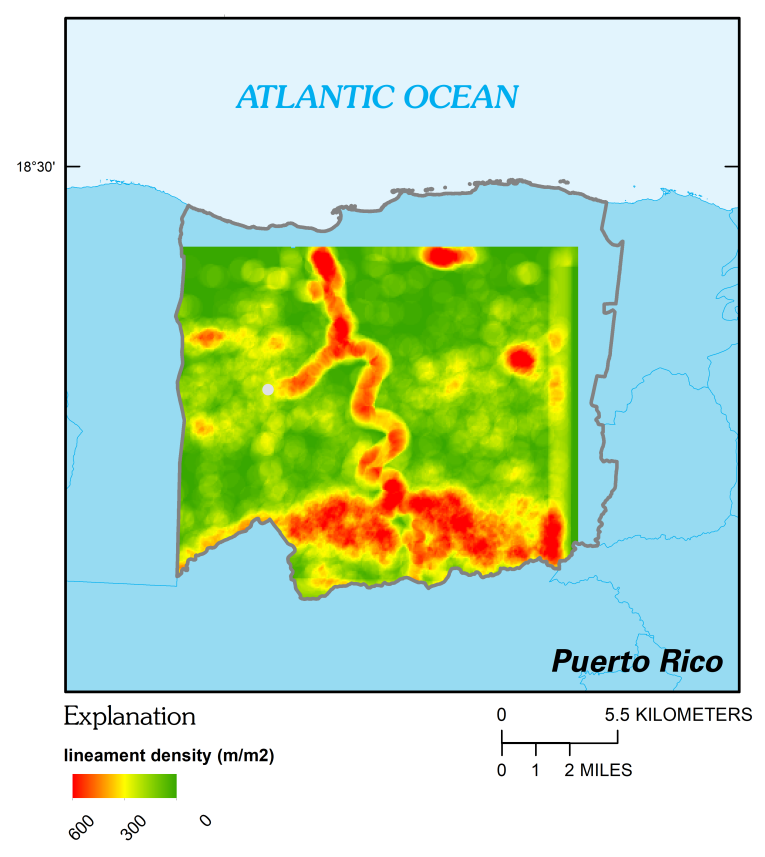

Figure 5. Lineament density thematic layer for the study area. 


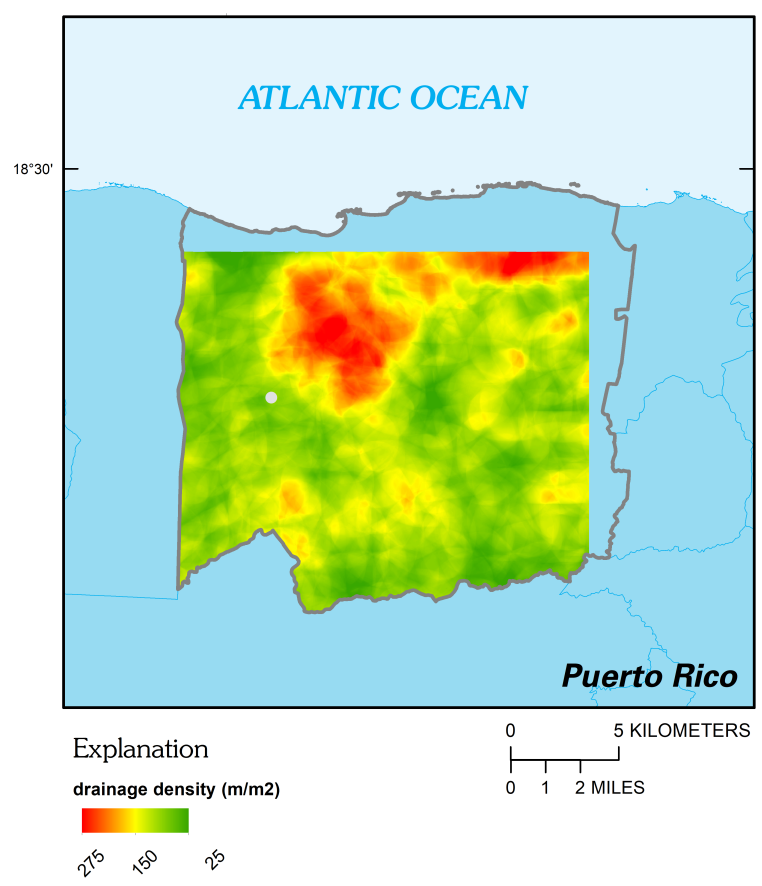

Figure 6. Drainage density thematic layer for the study area.

\section{Topographic Wetness Index}

The Topographic Wetness Index (TWI) provides a means to quantify how topography influences hydrological processes. It is commonly used to quantitatively simulate soil moisture conditions in a watershed (Ma et al., 2010). Applications of TWI include the study of processes, such as the spatial scale effects on hydrological processes and models, the identification of hydrological flow paths for geochemical or pollutant transport modeling, and the mapping of soil organic matter (Schmidt, 2003). TWI is defined as,

$$
T W I=\ln \frac{\alpha}{\tan \beta}
$$

where $\alpha$ is the cumulative upslope drainage area per unit contour length and $\tan \beta$ is the surface slope gradient. The TWI for the study area was obtained through the raster calculator tool in ArcMap 10.7 using the equation described above. The TWI calculated for the region (is depicted in Figure 7.

\section{Slope}

The steepest slopes are commonly associated with lower infiltration because water runoff is less able to infiltrate the surface and recharge saturated zones (Yeh et al., 2018). Infiltration is, therefore, expected to occur to a

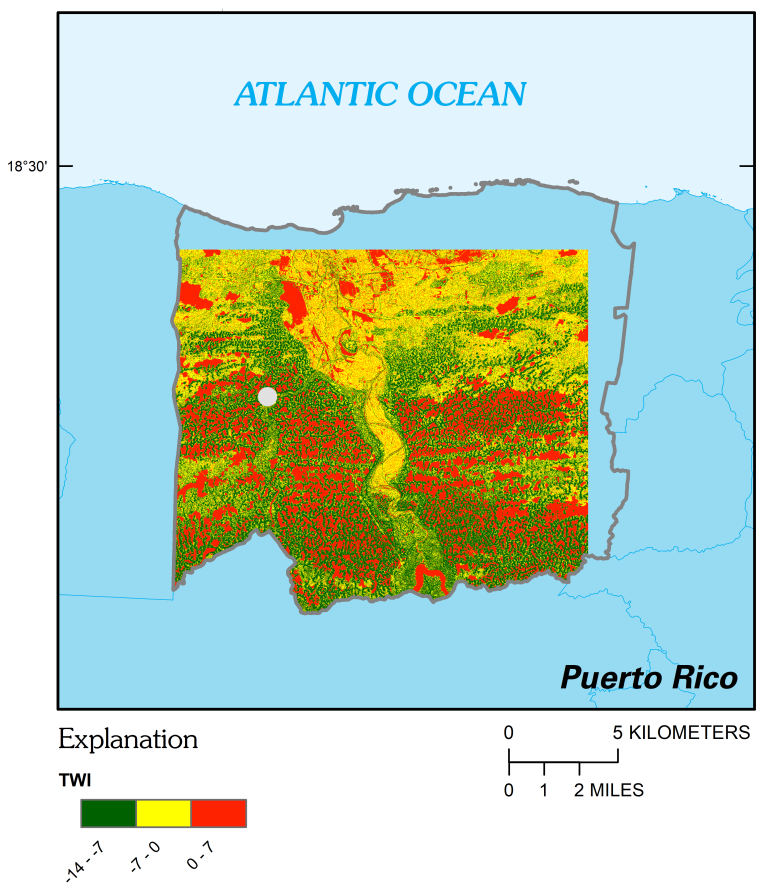

Figure 7. TWI thematic layer for the study area.

higher degree in low lying valleys and, in the case of karst systems, through sinkholes. The slope thematic layer for the study area (Figure 8) was generated using the slope tool in ArcGIS. It shows, as expected, lower slopes toward the coastal areas to the north, and reflects the karstic hill (Figure 2) topography toward the southern region of the study area.

\section{Land Use/Land Cover}

The different land use classes considered for the thematic map include agriculture, bare soil, forest, urban/rural and water bodies. The weights for each are summarized in Table 1. Agricultural and forest areas are known to contribute more to infiltration, and hence recharge, than populated areas, which are mostly impervious. The land use thematic layer in presented in Figure 9.

\section{Sinkhole Density}

Sinkholes are commonly encountered in karst regions and may be used to infer physical-chemical properties of the area (Giusti, 1978). Topographic maps and contour intervals of 5 and $10 \mathrm{~m}$ were employed by Giusti to develop a quantitative map of karst development percentage per unit area. A digitized version of the sinkhole distribution in the study area (adapted from Giusti, 1978) was provided by Torres et al. (2018). A close correlation between sinkhole density and recharge potential can be 


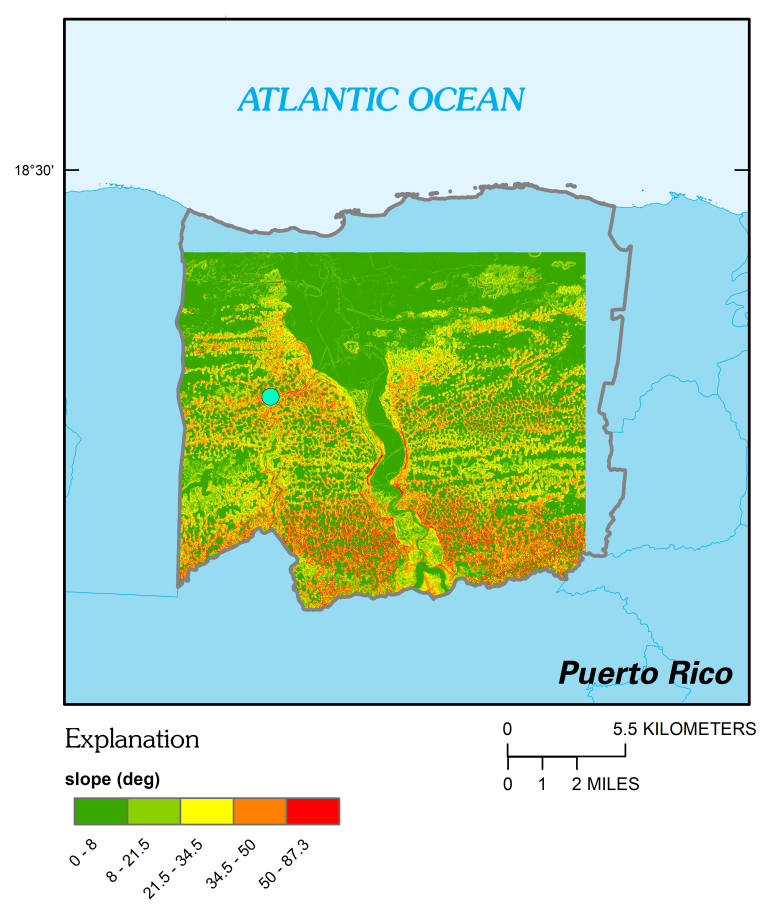

Figure 8. Slope thematic layer for the study area.

hypothesized. The modified sinkhole density used for the groundwater recharge potential study is shown in Figure 10.

\section{Results}

A depiction of the groundwater recharge potential map is shown in Figure 10. Based on the assigned weights and percent influences selected, it shows that potential recharge is more likely to occur in the limestone areas near the river basins that receive the most rainfall. Since both ground and surface water in the northern karst region moves regionally northward toward the Atlantic Ocean (Ghasemizadeh et al., 2012), it is to be expected that the drainage density follows this pattern, showing higher values particularly near the Río Grande de Arecibo basin, and toward the coast, where significant superficial water discharge occurs. In terms of soil moisture, the TWI calculated for the region showed higher values toward the coast due to low-lying areas in the karst water-

\begin{tabular}{lc}
\hline \multicolumn{1}{c}{ Recharge potential } & Area \% \\
\hline Very low & 0.4 \\
Low & 23.5 \\
Moderate & 63.4 \\
High & 12.7 \\
\hline
\end{tabular}

Table 3. Percent of recharge potential.

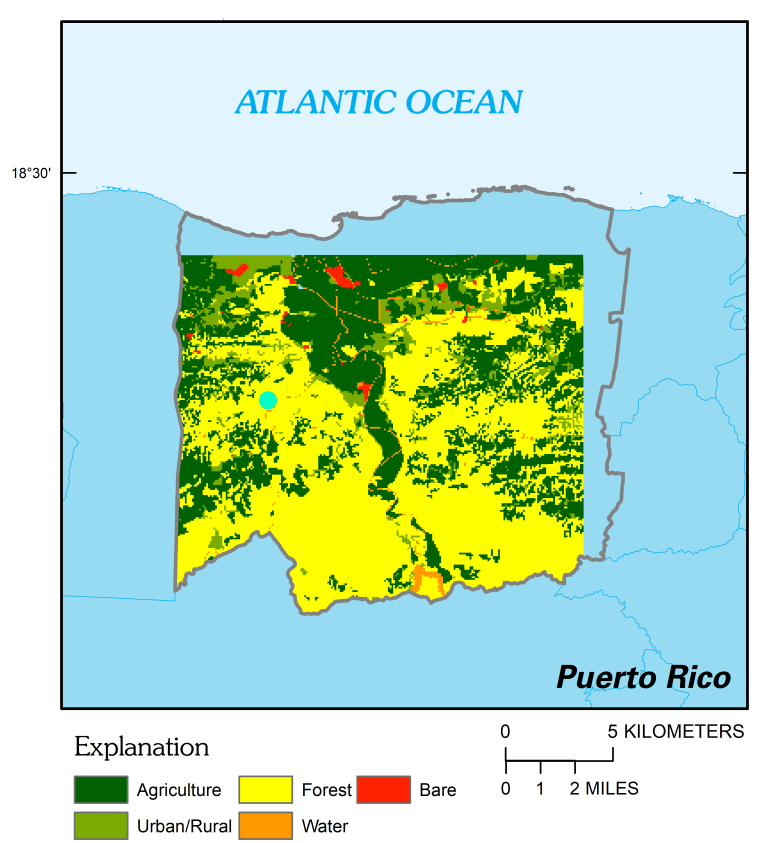

Figure 9. Land cover/land use thematic layer for the study area.

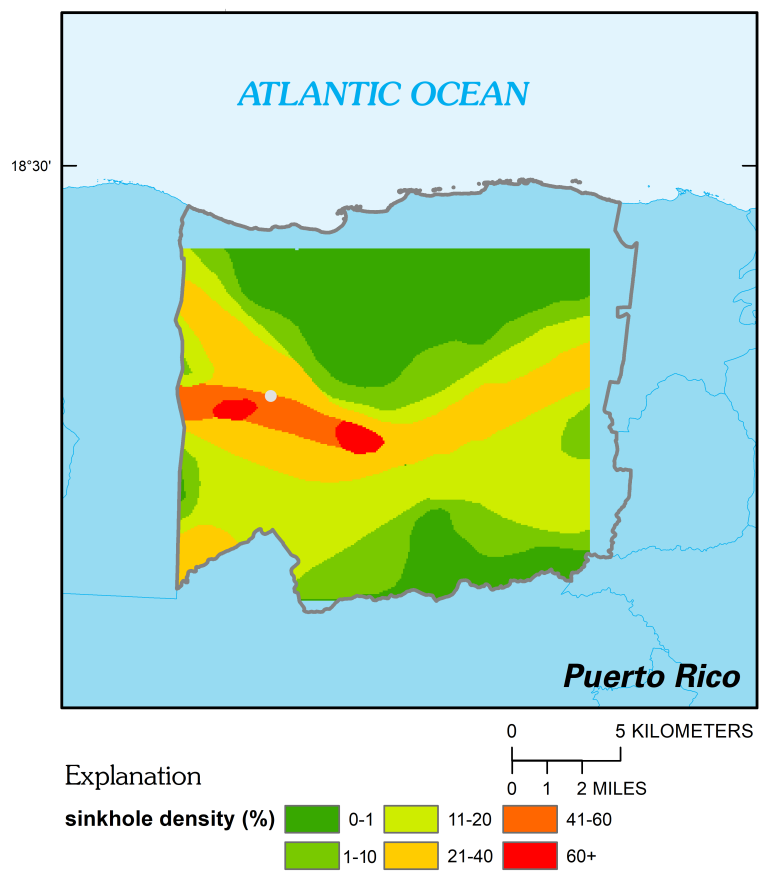

Figure 10. Sinkhole density thematic layer for the study area.

shed. Analysis also shows, as expected, that areas with steep slopes are represented by lower TWIs. In terms of land use, it can be seen that groundwater recharge is more likely to occur in agricultural and forested areas. 


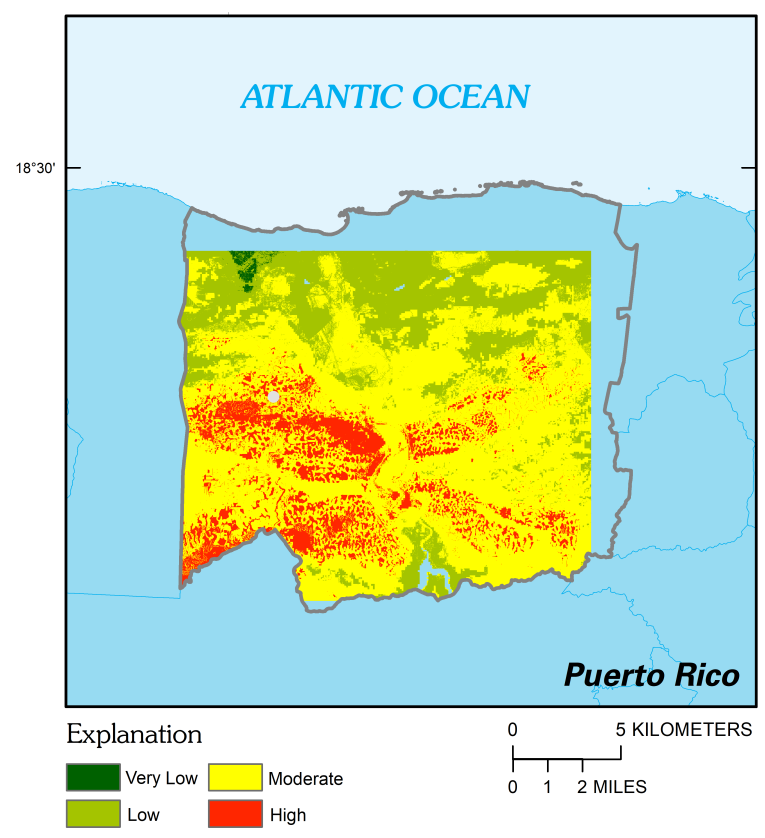

Figure 11. Groundwater potential recharge map.

\section{Conclusions}

Delineation of groundwater recharge potential zones in the northern karst belt region of Puerto Rico was achieved through the use of GIS techniques and unsupervised learning. Groundwater recharge parameters such as land use/cover, slope, geology, lineament and drainage density, precipitation, topographic wetness index (TWI), and sinkhole density were integrated by employing the weighted overlay tool in ArcGIS. Results of this analysis reveal a $76 \%$ moderate-to-high groundwater recharge capability in the study area. The suitability of employing RS and GIS techniques map and the methodology employed in this study will serve as the basis for further study regarding water management projects in Puerto Rico. Even though this methodology was implemented as a case study, it can certainly be extrapolated to other regions and can provide critical information regarding sustainable groundwater resource management.

\section{Acknowledgments}

This research is provided through Award Number P42ES017198 from the National Institute of Environmental Health Sciences of the National Institute of Health to the Puerto Rico Testsite for Exploring Contamination Threats (PRoTECT) Superfund Research Program Center [Grant number P42ES017198]. The authors express their appreciation to all PRoTECT Trainees from UPRM.

\section{References}

Abdullahi BU, Rai JK, Momoh M, Udensi EE. 2013. Effect of lineaments on groundwater occurrence; Int J Env Bioenergy 8 (1): 22-32.

Andualem T, Demeke G. 2019. Groundwater potential assessment using GIS and remote sensing: A case study of Guna tana landscape, upper Blue Nile Basin, Ethiopia. Journal of Hydrology: Regional Studies 24:100610. https://doi.org/10.1016/j. ejrh.2019.100610.

Chandio IA, Matori ANB, WanYusof KB, Talpur MAH, Balogun AL, Lawal DU. 2013. GIS-based analytic hierarchy process as a multicriteria decision analysis instrument: a review. Arab J Geosci. 6 (8): 3059-3066.

Chowdhury A, Jha MK, Chowdary VM. 2010. Delineation of groundwater recharge zones and identification of artificial recharge sites in West Medinipur District, West Bengal using RS, GIS, and MCDM techniques. Environ Earth Sci. 59 (6): 1209-1222.

Da Costa A, De Salis H, Viana J, Leal Pacheco F. 2019. Groundwater Recharge Potential for Sustainable Water Use in Urban Areas of the Jequitiba River Basin, Brazil. Sustainability. 11 (10): 2955. https:// doi.org/10.3390/su11102955.

Dasgupta S, Mukherjee S. 2018. Remote sensing in lineament identification: Examples from western India. Problems and Solutions in Structural Geology and Tectonics. https://doi.org/10.1016/ B978-0-12-814048-2.00016-8.

Ford D, Williams P. 2013. Karst Hydrogeology and Geomorphology. New York, NY: John Wiley \& Sons.

Giusti EV. 1978. Hydrogeology of the karst of Puerto Rico. Geological Survey Professional Paper 64: 6.

Jha MK, Chowdary VM, Chowdhury A. 2010. Groundwater assessment in Salboni Block, West Bengal (India) using remote sensing, geographical information system, and multi-criteria decision analysis techniques. Hydrogeol J. 18 (7): 17131728.

Ma J, Lin G, Chen J, Yang L. 2010. An improved Topographic Wetness Index 
considering topographic position. 2010 18th International Conference on Geoinformatics, Beijing. 1-4p. https://doi.org/10.1109/ GEOINFORMATICS.2010.5567607.

Molina-Rivera WL, Goméz-Goméz F. 2008. Estimated water use in Puerto Rico. Geological Survey Open-File Report 2014-1117, 35 p. https://doi. org/10.3133/ofr 20141117.

Monroe WH. 1976. The karst landforms of Puerto Rico. Geological Survey Professional Paper 69. 9-18p.

Schmidt F, Persson A. 2003. Comparison of DEM data capture and topographic wetness indices. Precision Agriculture 4: 179-192. https://doi. org/10.1023/A:102450 9322709.

Steele-Valentín KM, Padilla IY. 2009. Assessment of potential exposure pathways in karst groundwater systems in Vega Alta, Puerto Rico using Geographic Information Systems. Seventh LACCEI Latin American and Caribbean Conference for Engineering and Technology (LACCEI'2009); San Cristóbal, Venezuela. WE1 $1-11 \mathrm{p}$.

Todd D. 2009. Groundwater hydrology. John Wiley \& Sons.

Torres-Gonzalez A. 1985. Simulation of ground-water flow in the water table aquifer near Barceloneta, Puerto Rico. United States Geological Survey water resources investigations report 84-4113.

Torres-Gonzalez S, Planert M, Rodriguez JM. 1996. Hydrogeology and simulation of ground-water flow in the upper aquifer of the Rio Camuy to Rio Grande de Manati area, Puerto Rico. United States Geological Survey [USGS]; [cited 2019 Sept 10].

Torres NI, Rivera VL, Padilla IY, Macchiavelli RE, Kaeli D, Alshawabkeh AN. 2019. Effect of hydrogeological and anthropogenic factors on the spatial and temporal distribution of CVOCs in the karst system of northern Puerto Rico, Environmental Earth Sciences 78, 594. https://doi. org/10.1007/s12665-019-8611-7.

Torres NI, Yu X, Padilla IY, Macchiavelli RE, Ghasemizadeh R, Kaeli D, Cordero JF, Meeker JD, Alshawabkeh AN. 2018. The influence of hydrogeological and anthropogenic variables on phthalate contamination in eogenetic karst groundwater systems, Environmental Pollution 237: 298-307. https://doi.org/10.1016/j. envpol.2018.01.106.

Veni G, DuChene H, Crawford NC, Groves, CG, Huppert, GH, Kastning EH, Olson R, Wheeler, BJ. 2001. Living with karst: A fragile foundation. Environmental awareness series: Alexandria, Virginia, American Geological Institute. 64 p.

Veve TD, Taggart BE. 1996. Atlas of ground-water resources in Puerto Rico and the U.S. Virgin Islands. Water-Resources Investig Rep 94-4198.

Weary D, Doctor D. 2014. Karst in the United States: a digital map compilation and database. U.S. Geological Survey Open-File Report 2014-1156, 23 p. https://doi.org/10.3133/ofr20141156.

Yeh H, Lee C, Hsu K, Chang P. 2008. GIS for the assessment of the groundwater recharge potential zone. Environmental Geology 58: 185-195.

Yu X, Ghasemizadeh R, Padilla I, Irizarry C, Kaeli D, Alshawabkeh A. 2015. Spatiotemporal changes of CVOC concentrations in karst aquifers: Analysis of three decades of data from Puerto Rico. Science of The Total Environment 511: 1-10. 